\title{
All Ranks Are Local: Why Humans Are Both (Painfully) Aware and (Surprisingly) Unaware of Their Lot in Life
}

\section{Citation}

Norton, Michael I. "All Ranks Are Local: Why Humans Are Both (Painfully) Aware and (Surprisingly) Unaware of Their Lot in Life." Psychological Inquiry 24, no. 2 (2013): 124-125.

\section{Published Version}

http://www.tandfonline.com/doi/full/10.1080/1047840X.2013.794689

\section{Permanent link}

http://nrs.harvard.edu/urn-3:HUL.InstRepos:11320615

\section{Terms of Use}

This article was downloaded from Harvard University's DASH repository, and is made available under the terms and conditions applicable to Open Access Policy Articles, as set forth at http:// nrs.harvard.edu/urn-3:HUL.InstRepos:dash.current.terms-of-use\#OAP

\section{Share Your Story}

The Harvard community has made this article openly available. Please share how this access benefits you. Submit a story.

Accessibility 
All Ranks Are Local 1

All Ranks Are Local:

Why Humans Are Both (Painfully) Aware and (Surprisingly) Unaware of Their Lot in Life

Michael I. Norton

Harvard Business School

In Press, Psychological Inquiry 
Moments in life that involve discovering one's social rank are among the most emotionally evocative that humans experience. Reflect for a few moments on a time you came in first in some pursuit. Now do the same, but for a time you came in last. Remembering that science prize in middle school felt great - but the pain of that last-place finish in the 100-yard dash still stings. Kraus, Tan, and Tannenbaum (2013) marshal an impressively interdisciplinary set of data to document the pervasiveness and power of rank in everyday life. From health to happiness to social interactions, rank matters, and is a key predictor of outcomes.

Yet, an interesting puzzle arises in the study of rank. People can be totally unaware of the shape of the distribution, and even of their place in that distribution - which would seem to suggest that rank doesn't matter that much. And yet, as the research summarized in Kraus et al. (2013) demonstrates, rank also seems to matter immensely. How can people be so surprisingly unaware of their lot in life, yet be painfully affected by it at the same time?

First, the lack of awareness. In a recent study, Norton and Ariely (2011) asked a national sample of Americans a series of seemingly simple questions about how wealth was distributed among Americans. Specifically, respondents were asked to estimate the percentage of all the wealth in the United States that was owned by the richest $20 \%$ of Americans, the second richest $20 \%$, and so on, down to the poorest $20 \%$. They estimated that the richest quintile owned about $60 \%$ of the wealth and that the bottom $40 \%$ owned about $10 \%$ - in other words, they reported that wealth was quite unevenly distributed. The problem is that these estimates, while directionally accurate, are surprisingly inaccurate. In fact, the richest quintile owns about $85 \%$ of all the wealth - a full $25 \%$ more than respondents estimated - while the poorest $40 \%$ of Americans basically own nothing. And rich respondents and poor respondents were equally erroneous in their estimates, suggesting that for one of the most salient markers of rank - wealth 
- people are not even aware of the shape of the distribution.

Not only that, but people also appear to be unaware of their place in that distribution. In a survey conducted in Argentina, respondents were asked, "There are 10 million families in Argentina. Of those 10 million, how many do you think have an income lower than yours?" Because the researchers also collected data on respondents' household income, they were able to assess the accuracy of respondents' beliefs. Interestingly, the most stringent criteria suggested that a paltry $15 \%$ of Argentinians placed themselves in the correct income quintile; even a more lenient analytical approach suggested that a full 55\% of Argentinians displayed at least some error in their estimate (Cruces, Perez-Truglia, \& Tetaz, 2013). Taken together, Cruces et al. (2013) and Norton and Ariely (2011) offer support for the notion that people do not know their lot in life, and do not even really know the shape of the distribution from which those lots are drawn.

How can people be unaware of such basic facts about ranks, yet be so deeply influenced by their rank? The answer lies in a modification of a famous saying by former US Congressman Tip O’Neill: all ranks are local. The broad shape of an overall distribution of outcomes matters much less than the local shape of an individual's most salient distributions: when you came in last in that 100-yard dash, you compared yourself only to your classmates, not the 100-yard dash times of all 12-year-olds in the world. (Though if we are being honest with ourselves, the average academic is probably still pretty near the bottom of any speed-related distribution). This is why interesting results like those in Boyce, Brown, and Moore (2010) emerge: people's own income means little for their happiness until they compare it to the income of others.

This general lack of awareness of rank coupled with the powerful effects on humans once ranks are known offers enormous potential for social scientists to conduct experiments to "get 
under the hood" of the psychology of ranks. In other words, if people did have full information on distributions and their place in those distributions, social scientists could simply measure objective characteristics of people (their income, etc.) in order to predict their behavior. Instead, because rank is constantly constructed in the situation - by who and what is salient for comparison at any point in time - research exploring the many ways in which ranks affect thought, emotion, and behavior is just getting underway. Indeed, in the Cruces et al. (2013) research described above, lower income individuals who were informed that they were lower in the income distribution than they predicted subsequently became more in favor of policies that benefited the poor: once they knew they were poor, their attitudes shifted accordingly (see also Kuziemko, Norton, Saez, \& Stantcheva, 2013).

Two recent examples are instructive, both of which stand in contrast to conventional wisdom about how ranks should work, and instead offer insight into the psychology of how ranks actually work. Consider the commonly-stated assumption that poorer individuals will spend a larger percentage of their income on "conspicuous consumption" - status-conferring products such as luxury brands - as the gap between themselves and the rich grows wider and wider (e.g., Elster, 1991). Instead, Ordabayeva and Chandon (2011) explored whether such consumption is motivated not by the desire to "beat the rich," but instead to gain local status. They show that in fact, people are more likely to engage in conspicuous consumption - for example, upgrading their flower gardens - when those around them have more equal outcomes than when there is more inequality. Why? Because in a relatively flat distribution, engaging in one additional purchase leapfrogs the buyer over every other person in the neighborhood for the top rank.

Or, take Karl Marx's oft-repeated prediction that the workers of the world will unite and 
overthrow the rich. Again, the assertion makes intuitive sense: why wouldn't people in the bottom income quintiles gang up on the rich? As it turns out, the poor are more likely to focus on their relative rank than their absolute rank; in fact, if anything, research exploring "last-place aversion" reveals that people near the bottom of the income distribution are more likely to treat each other badly than wealthier individuals (Kuziemko, Buell, Reich, \& Norton, 2013). In these experiments, people are randomly assigned to a rank in an "income distribution" where everyone is separated by $\$ 1$. They are then asked to whom they'd like to give a $\$ 2$ bonus payment: the person directly above them, or the person directly below them. Even though giving to the person below means that he will "leapfrog" over you in the distribution, most people give to the person below: in most circumstances, giving money to someone who already has more than you is apparently not very appetizing. But last-place aversion suggests one crucial exception to this general rule: anyone in second-to-last place would be less enthusiastic about giving to the person below, because doing so moves the second-to-last place person into last place. And indeed, compared to people in all other ranks, between a half and a third of people in second-to-last place choose to give money to the person above rather than the person below, in order to ensure staying out of last. Simply put, an inherent aversion to being at the very bottom of a distribution (think of the shame of being picked last for a team in gym class) makes people with belowaverage income wary of redistribution, in case that redistribution helps even worse off individuals rise above them in rank.

In sum, the research reviewed above offers support for the notion that all ranks are local. People are unaware of the shape of the distribution of outcomes and their specific rank in that overall distribution, yet when made aware of their local rank, their preferences and behavior shift can dramatically. Together with the framework outlined in Kraus et al. (2013), these findings 
All Ranks Are Local 6

offer the beginning of a rich area of research in psychology that further explores the psychology of ranks. 


\section{References}

Boyce, C. J., Brown, G. D. A., \& Moore, S. C. (2010). Money and happiness: Rank of income, not income, affects life satisfaction. Psychological Science, 21, 471-475.

Cruces, G., Perez-Truglia, R. \& Tetaz, M. (2013). Biased perceptions of income distribution and preferences for redistribution: Evidence from a survey experiment. Journal of Public Economics, 98, 100-112.

Elster, J. (1991). Envy in social Life. In R.J. Zeckhauser (Ed.), Strategy and choice (pp. 49-82). Cambridge, MA: MIT Press.

Kraus, M.W., Tan, J., \& Tannenbaum, M.B. (2013). The social ladder: A rank-based perspective on social class. Psychological Inquiry.

Kuziemko, I., Buell, R.W., Reich, T., \& Norton, M.I. (2013). Last-place aversion: Evidence and redistributive implications. Manuscript submitted for publication.

Kuziemko, I., Norton, M.I., Saez, E., \& Stantcheva, S. (2013). How elastic are preferences for redistribution? Evidence from randomized survey experiments. NBER Working Paper Series, No. 18865.

Norton, M.I. \& Ariely, D. (2011). Building a better America - one wealth quintile at a time. Perspectives on Psychological Science, 6, 9-12.

Ordabayeva, N. \& Chandon, P. (2011). Getting ahead of the Joneses: When equality increases conspicuous consumption among bottom-tier consumers. Journal of Consumer Research, $38,27-41$. 